\title{
Conservatism and Turkey: Case of Motherland Party
}

\author{
Onur Kulaç \\ Research Assistant, Department of Political Science and Public Administration, \\ Faculty of Economics and Administrative Sciences, Pamukkale University, Turkey \\ Email: onurkulac@yahoo.com \\ H. Serhan Çalhan \\ PhD Candidate, Department of Political Science and Public Administration, \\ Institute of Social Sciences, Pamukkale University, Turkey \\ Email: serhancalhan@hotmail.com \\ Mehmet Tuğral \\ MA Candidate, Department of Political Science and Public Administration, \\ Institute of Social Sciences, Pamukkale University, Turkey \\ Email:mehmettugral@hotmail.com
}

\section{Doi:10.5901/mjss.2014.v5n7p548}

\section{Abstract}

\begin{abstract}
Conservative ideology which is a modern movement as opposed to Western modernisation emerged in the 18th century. Conservatism has been reshaped by various interpretations in different countries; states and the societies has been highly affected by this ideology. The concept of conservatism had an impact on politics and the society in the last period of Ottoman Empire which is not familiar to the West countries practices. Even the studies about conservatism has not been considered crucial for a long time, the emergence of Motherland Party and the Justice and Development Party which define their political view as democratic conservatism in Turkish political life have increased the number studies dramatically related to conservatism. In this study firstly, definitions and the characteristics of conservatism will be scrutinized according to different academicians. Furthermore, the fundamental principles of conservatism are examined and evaluated in detail. Lastly, how conservatism emerged in Turkey and what are differences and the similarities between Turkey and the West in case of conservatism will be analysed in dept. In the qualitative part of the study, the concept of conservatism will be discussed in case of Turgut OZAL who was the founder of the Motherland Party in Turkey. On the other hand, the common points of Motherland Party and Development and Justice party in terms of parties programs and leaders discourses will be put forth.
\end{abstract}

Keywords: Conservatism, Motherland Party, Conservatism in Turkey, Justice and Development Party

\section{Introduction}

In the historical process, political ideologies took a major part shaping the societies. Political ideologies grew in number in time and each of them presented their own world views. Also conservatism came out at the end of the 18th century against the French Revolution and Enlightenment Movement; the bases of conservative thinking laid in England and Germany. With the reinterpretation in North America, the conservatism enlarged its own theoretical territory. However, in Turkey conservative thinking had changes due to the periodic variations. Although conservative thinking found important utilization areas to itself in Ozal period after 1980, conservatism was approached differently in Ozal period. In this study it is firstly investigated how conservative ideology came out and how specific countries approached it. Secondly, the basic themes of the conservatism are presented and it is being compared with Liberal thinking. Lastly, historical developments of Turkish Conservatism and in detail conservative thinking in Motherland Party period are being handled.

\section{The Concept of Conservatism}

Defending the protection of existing political, social and economic order, conservative thinking comes out at the end of the 18th century against French Revolution. Came out as a reaction to the changes in different areas that French 
Revolution lead to, conservatism was accepted in Germany in 1830s, and in England in 1835 and the Main Opposition Party's former name Tory was changed into "Conservative Party" (Heywood, 2011:83). The bases of the conservative thinking were laid by Edmund Burke. Burke's book, Reflections on the Revolution in France played a significant role in clearer understanding of conservative thinking. This work put forth by Edmund Burke seen as the Das Capital of the conservative political philosophy (Vural, 2003: 22). Burke, who was generally effective on shaping the English Conservatism, never stood against changing bluntly; moreover, he supported changing in order to protect (Heywood, 2011: 83). As the conservatism is basically a reaction movement against French Revolution and modernisation in the West, it is hard to come across with a conservative approach in places rather than Europe and North America. However, there had been other reaction movements in Africa, Asia and Latin America which resist changing and try to protect their lifestyle (Heywood, 2011:84).

According to the conservative thinking, the old order is the one which is the most beneficial to the widest segment of society. Civil society, whose basis is formed by the religion and constituting all kinds of "goodness" and "wealth", is the product of a traditional settlement. If this compromise and ground are corrupted, every person will work for their own personal goals, he will become the judge of his own actions and at the same time he cannot benefit from the rights of civilians and non-military society (Burke, 1986: 150). Conservatism regards the elements, surrounding human beings in a compatible way, as random and belonging to the world order, and therefore it sees the cause as unproblematic. For this reason, it is said that there is no conservative utopia of consciousness and in fact there is rule information. (Mannheim, 2002: 251)

As in all other political theories, conservatism has different traditions and it differs in the values it defended in 19th and 20 th centuries. This thinking which mainly defended monarchy and aristocracy in the 19th century, changed its vision as state intervention in 20th century. Even though its reaction bases against the French Revolution and modernism in the West, the conservational thinking is also stand against the developments like Industrial Revolution, mechanization, urbanization, population growth which had ruined the old system in both politics and social life (Örs, 2012:123).

\section{Basic Themes of Conservatism}

Conservative theory which is a contemporary political thought has some main themes. These themes can be counted as Tradition and Religion, Human Imperfection, Organic Society, Hierarchy and Authority and Property.

\subsection{Tradition and Religion}

In contrast to the Liberals, the Conservatives give major importance to the protection of institutions and traditions that are resisting the time and protecting its values. Even though the liberals support the restoration or the removal of the institutions that have lost their functions, conservatives believe that these institutions passed the history test successfully and proved themselves. According to conservatives, the institutions and the traditions that are the legacy of history are sacred and if people stand up against them, that means they also stand against the God too. The conservatives legitimized tradition understanding by combining it with the religion (Heywood, 2011: 86-87).

Conservatives highly respect to the tradition and think that tradition gives them belongingness being rooted. Also, as they believe that the traditions are for the good of the following generations, they emphasize that it needs to be wellprotected and passed to them neatly. Always conservative approach to change is in a negative way and they believe that change leads people to and unknown, blurred journey and diminishes trust (Heywood, 2011: 88-89). Being one of the major themes of conservative thinking, traditional idea gets attention by the importance that is given and present major differences with the traditional understanding of Liberalism which is another modern political theory.

In conservative thinking there is a high emphasis on religion. They think that religion is important for the human beings lack morality and it contributes to the society's soul and life. Conservatives support that religion motivates society in terms of morality and ethics and build social unity and solidarity (Çaha, 2004: 78-79). It is not so true to say that conservative understanding of religion is being an extremist. Conservatives think that religion is not only an individual notion but a communal one and religion is the institution that creates communal unity and solidarity.

According to Burke, religion, being one of the biggest bonds of society, would present an instrumental nature. During a trip to France, he was appalled by the Paris salon of obvious atheism and he began to hold meetings on tolerance at home when returned home. According to him, atheism is the most disgusting and terrible blow that can be offered to the community and they are all gone out of the constitution of the human race, not only France. (Monk, 2004 : $346-347)$. 


\subsection{Human Imperfection}

Human deficiency understanding is among the conservative thinking's basic themes. According to the conservatives, human nature is deficient and defective. Despite the other political theories defend that the human is a good being as a nature, according to the conservatives human beings are restricted and morally tend to be bad. Conservatives think that the human intelligence cannot understand this sophisticated world and so the thoughts should be based on only tradition and experience. Freedom is such a dangerous concept for the conservatives and they support the idea that it would drag them to a misty path. Unlike Liberals state that the reason is not injustice or social disadvantages for the crime notion among the society, conservatives defend that the instincts and the lust in individuals have makes the base of it. According to the conservatives, individuals should be cautious for the world, modest and they should avoid dogmatic beliefs (Heywood, 2011: 88-89). Burke states that society is a collective entity made up of individuals and any policy, harmful to individuals, will not be beneficial to society, either. However; Burke persistently opposes to anarchism which degrades individuals "summer to fly" ( Kirk , 2005 : 21).

\subsection{Organic Society}

In conservatism the society is highly important. Although the Liberals think that the society is nothing else but the actions of the individuals who only search for their own good, conservatives believe that society gives individuals a meaningful and safe life. According to conservatives, human beings naturally search and need for safety throughout their lifetime. Conservatives, who thinks that individuals cannot be separately thought from society, see the family as the society's very basic institution. According to conservatives, for a healthy society the importance that is given to the family should be raised and the family institution should be made more powerful (Heywood, 2011: 90-91).

According to conservatives society is like an organism coming from the history and leading towards the future and under no circumstances it should be intervened. The conservatives who believe that the society is an alive and perfect structure defends that one thing that is affecting a piece of society eventually affect the whole. Continuity in society is very important and it should never be interrupted. Society is founded by experience, not by intelligence and in this process tradition, ethics, morals and habits play a very important role (Çaha, 2004: 19-21).

The society which has an organize structure is made of different members and every member has a unique speciality and job. According to Macridis this relationship is something like this: "Every single peace is aware of this mutuality. Each of them do their own work, however, the think that makes them meaningful is that their understanding and evaluation of this. Farmer grows crops, soldiers protect and guard the order, priests glorify our thoughts and soul and the leaders run and balance some specific peace. In the case of their separation almost all pieces lose their meaning." (Özipek, 2004: 76). According to Burke, society is neither a loose collection of community members with ties nor a mechanism which has interchangeable parts among them. It is a living organism. An event that affects a part of society affects it all (Harries, 2004: 93). As a result, conservatives defend the idea that the society has an organic structure and it progress naturally. According to the conservatives in order not to ruin the society's harmony, we need to stay away from social engineering.

\subsection{Hierarchy and Authority}

Conservatives think that the authority notion also progress naturally in the society. According to the conservatives, the development behind the state's becoming a despot leviathan is that creating a objective path to it with the effects of the Liberals. However, according to conservatism, the authoritarianism that is in social traditions is not a bad thing. The point is, this is the authority of a father also with mercy and compassion. Government is responsible for the civil that he's being a father to. It can carry this responsibility to points that are not despot only within the scope of its authoritarianism which is fed on again the civil (Ögün, 1997).

Conservatives always emphasize respect to the governmental authority and they believe that in a society without a governmental authority, instability would rule. According to the conservative thinking, it is stated that in the case of an endless power for the naturally bad human beings they will use it for the bad and it is believed that this freedom should be restricted and controlled. According to conservatives authority is compulsory and beneficial. It is possible to see authority in every corner of the society. Authority is used by teacher at school, boss at work; referee at a football game and by governments in the whole society. Among the conservatives there are little difference for the view of authority. While authoritarian conservatives defend that the authority is absolute and unquestionable, most of the conservatives think that authority needs to be in the lines that is drawn by social responsibilities (Heywood: 2011: 93-94). 
Human being builds over his identity regarding traditions and customs inherited from their ancestors. Society is similar to a tree, taking its roots from the depths of history. Its formation takes centuries and is a superstructure which has occurred from single individuals independently. Society, when needed, can take on another form by changing depending on its collective mind and the program. Change, when needed, occurs spontaneously and slowly (Rossiter, 1982: 27). Society has a shape which inferences cannot be grasped with the mental functioning, and an abrupt change leads to a destruction and chaos. Conservatives have been against every kind of social engineering. They liken the efforts, aimed to change the society based on rational principles and fiction, to shape the leaves of a tree, which should grow in the natural environment, That is, such an effort could lead to the destruction of the tree and break. (Oakeshott, 2001: 80-110,168196)

Conservatives and Liberals are on the same side about the social inequality. According to conservatives individual in the society differ from each other with their abilities, intelligences and because of this hierarchy is inevitable in a society that is shaped naturally. In organic societies, while some become the leader, some need to follow the others. Each individual has a different duty in society. Just like the human body: brain, heart, liver have very different duties, the groups and the classes in a society have their own, different roles (Heywood: 2011:94).

\subsection{Property}

In conservative thinking, property notion has an importance. Although conservatives believe that each individual has the equal rights, they state that this does not mean equal property owning. Conservatives defend that the properties are the proofs of merit and the ones who are capable; who work hard should have the properties. Properties give safety feelings and peace to the individuals in this doubtful world. Conservatives state that property notion is also important for the society's order and the individuals who have their own property are also show respect to other people's belongings too.

One of the most fundamental of human life is happiness (bliss) for the conservatives and it is achieved by meeting basic needs in the first phase. Therefore, according to conservatives, commercial activities of people and other ways of earning money should not be obstructed and people should be able to acquire property with their earnings. In order to perform these activities, there should be a market which goods and services are freely offered and sold in. (Honderich, 1990: 86-91)

Conservatives who believe that the properties should be protected by the government also state that the property issue is not only an individual situation but also it should interest the society closely. According to the conservatives properties are not only the existing generation's savings and most of them have been inherited from the previous generations.

Because of this, today's generation should keep this inheritance in the best way, protect it and hand down the next generations in a good shape. As a result, conservatives express the importance they give to the property notion clearly and they are in more parallel ways with Liberals in this topic (Heywood: 2011: 94-95).

\section{Turkish Conservatism}

After declaring itself as a conservative-patriotic coalition, the Motherland Party, which came to power after the 1983 general elections, arouse interest in Turkish attitude of mind (Irem, 1997: 52-53). The Conservatism, which has a rich philosophy and is based on French Revolution, was born into an understanding of a radical modernism which legitimates economic and political institutions like nation-states and capitalism which proceed with modernisation movements of Kemalizm. Conservation came forward and was understood in various ways by different governments. Turkish Conservatism was affected by different movements from the West and created a synthesis.

According to Çaha (2004: 18), the conservatism in Turkey is based on a dominant, surrounding and authoritarian state understanding as in the German and French tradition from a liberal point like Anglo-Saxon conservatism. There was a dominant conservatism dubious to run in with democracy along with a conservatism vein that supports Turkish liberal and democracy thinking. It can be stated that, in Turkey, although the central right wing politics is fed on a conservatism custom which is more likely to liberalism, the patriotic policies do more on dominant conservatism. In the studies of leading social scientists such as Niyazi Berkes and Kemal Karpat, conservatism/traditionalism does not consider as a special philosophical-political language. On the other hand, according to Berkes, in the Ottoman Empire, the most powerful representatives of the Turkish conservatism were the military forces, ulama and craftsmen. These three groups lost power and status with the innovation movements that the times required (Irem, 1997: 53-54; Aydın, 2008).

When the Western conservatism and the Turkish conservatism are compared, similarities and differences are come out. Both in the coming out of the Turkish conservatism and the Western conservatism, there is a reaction 
movement against the changes come with national or international aspects. In both cases there is a standing against the change and the change is blocked. As one of the main elements of the conservatism thinking, tradition is found in both and the important is given to utilizing the experience. Especially in political issues, the past experiences are highly benefitted. The synthesis of today and past on the Western and Turkish conservatism is on process and in the case of possible changes the importance is given to not to be alienated to the society's traditions. As the major point of the conservative thinking, religion takes place in both Turkish conservatism and Western conservatism and it especially takes role in regulation and stability of the social life. While Turkish conservatism denies inequality and hierarchy and stand up for popular sovereignty, Western conservatism stands against to popular sovereignty. In Turkish conservatism it can be seen that the public culture is represented, however, in Western conservatism aristocratic culture is being represented (Kolat: 2002, 67-68).

Unlike the French conservatism, Turkish conservatism is definitely not against neither the Republican regime nor its returns. Looking at the Turkish conservatism it can be seen that conservatism is not taken as a name but is seen as an adjective. Conservatism has been used to characterise different human constitutions. For example; statist conservatism, patriotic conservatism, culture conservatism, leftist conservatism, Islamic conservatism (Aydin, 2002, Irem, 1997). When we look at the historical improvement of the Turkish conservatism we can see that it lived its purest times in 1950s and the patriotic conservatism thinking was dominant in those times. Later on Turkish conservatism changed its shape as Islamic in 1970s, as Turkish conservatism in 1980s, and as conservative-democrat with Motherland Party and after Justice and Development Party (Okutan, 2004:34).

\title{
5. Motherland Party and Conservatism
}

The discourses of Motherland Party and especially the policies on different areas that the founder Turgut Ozal followed are important to understand Turkish conservatism after 1980 in Turkey. Looking back at the year 1983, the foundation year of the Motherland Party, the chairman Ozal introduced party to the public as (Anavatan Partisi Parti Programı, 1993: 2);

\begin{abstract}
"Motherland Party is a politic body that act out in the main boundaries of Republic of Turkish Constitution, Human Rights Declaration, Law of Political Parties and other laws... We are a Party that is based on Nationalist, Conservatism, social justice and competitive free market economy... This is a gate for serving. We believe that we can serve our people in the best way and wish our almighty Allah to help us in our efforts."
\end{abstract}

At the time of Ozal Motherland Party draw four politic paths to itself and tried to gather all four under the same roof. Although Motherland Party at Ozal period seems like Liberal, Nationalist, Conservative and Social democrat, actually the conservative side come to the fore. When looked at the Motherland Party's program, it is seen that they used a nationalist-conservative language. The family notion which is one of the basic values of the conservative thinking is again is one of the points that take place in the Party's program. In the Party's program, there are discourses like (1993: 24):

"Family is the base of our nation. The re-depiction and re-determination of the natural responsibility hierarchy of our family structure is necessary in order to maintain social life harmoniously and steadily, to raise youth, and to protect ethics, national and moral values."

The presence of the statements like homeland and nation integrity, respect to the ethics and traditions, protecting and keeping alive the national values in the Party program at the first years of Motherland Party show vividly the conservative identity of both the Party and the leader Ozal. Ozal points out that the conservative approach of the Motherland Party is not fanaticism for religion. In other words, the conservative approach of the Party is just to show respect to the values, history and beliefs and to protect these values and ethics in an avant-garde way. The introduction of the conservatism idea as fanaticism by some demagogue groups in purpose and using this as a down looking for the conservative people is an unacceptable situation by the Motherland Party. Also it is an unacceptable characterization considering our country's facts. The conservative approach of the Motherland is defined as the protection of being a nation, accumulation of a thousands of years' history and having a state tradition, the wholeness of values of being the centre and base of sharing a common destiny in today's and former geography (Dursun, 2004: 177-197).

Motherland Party defined itself as "Modern Conservative" and followed a path that takes protecting and developing national-moral values, humanist, and competitive politics as base in their own policies. Motherland Party gave big importance to the society and emphasized religion and family notions in order to lessen the effect of the market on society in the description of modern conservatism. Looking at the Turgut Ozal's approach on politics, it is seen that 
instead of being a status-quoist, he has a supporter of changing and rotation style. Compared to the Süleyman Demirel, in contrast to Demirel's vote-get service exchange understanding Ozal tried to make changes in economic and politic structure and revealed a revolutionist understanding. In the Ozal period Motherland Party became a new right-wing party by combining nationalist conservatism with liberalism. In his speeches Ozal generally differentiated that conservatism is not fanaticism and showed that he is open to everything that has practical benefit at public sphere and private sphere. In the Ozal period looking through what have done by means of right-wing policies we see big steps like foundation of Istanbul Stock Exchange, flexible exchange rate, industrial spurt suitable to foreign competition, removal of the export restrictions. Evaluating the Motherland Party and Ozal policies, the two major policies are providing free market economy and bringing the social statue back to a good position. As it can be seen by the policies, in the conservative understanding of Motherland Party both the value which is given to social patterns, traditions and the liberal approach in economic policies are considered primary (Morgil, 1996: 104).

In the post-Ozal period there had been changes in the party's conservatism understanding. In the Ozal period, the liberal issues of the fanatics inside of the Party had to stay on paper. Later on, especially in Mesut Yılmaz periods, despite the Liberal-Nationalist-Conservative Party descriptions, it can be seen clearly that Motherland Party moved away from the Conservative and Nationalist identity and had a more Liberal identity. The right-wing movement which was quite popular in the States and England was wanted to be implemented to Turkey in 1980s by Ozal and a new conservative understanding was internalized. The policies that Ozal utilized that had a massive effect on the period and the ideological approaches gave the name "Ozalizm" to the period. The intention to gather all contrast ideas of Motherland Party under a roof unsettled the conservative identity considerably and especially after Ozal period conservative approach was totally deleted from the party's identity. Göle sited that the qualifications of the Motherland Party is not suitable for the conservative understanding and gathered the Party's identity under three topics. According to Göle (2002: 45-46) the first one of these identities pioneered to the process with moderate approach in order to have negotiations, not fighting. Secondly, using their operations rather than rhetoric, Motherland Party took first justifying pragmatic values more than ideological values.

Thirdly, the synthesis that Motherland Party tried to make between market rates and Islamic conservatism reveals the identity of the Party. Motherland Party who take themselves as modern conservatives, on cultural basis include both conservative values coming from Islam especially on family-individual relationship, and rationalist values that fit to the engineering formation. In this way, Islamic engineers have been trying to combine values of conservative local culture with rationalism of the modern Western culture. Comparing the Motherland Party and other conservative political parties, along with the similarities, basic differences can be seen. Bora and Erdogan (2003: 644) explains the similarity and difference between Ozal and Demirel as the development that Ozal, who is a typical representative of New Right-wing that joins national conservatism to neoliberalism to create a Muslim-based Turkish society which is suitable for the era, protective to ethics and morals, capable of a selective modernism overlaps the liberal-conservative line that Demirel legitimized by referring to the public's conventional wisdom.

The reason of Ozal's different approach to this topic is his more onrush interest in pragmatic modernism. Using Quran, the azan, flag words in his speeches, the chairman of Motherland Party and Democratic Party leaves a conservative impression at the public's eye. There can be seen many similarities in many topics between Ozal and today's ruling Justice and Development Party leader Erdogan. Güneri Civaoglu, Milliyet newspaper columnist, sums this in his article in 2004 as: Gaining the elections the same year that they were founded, mentioning breaking the status quo and change, being in a relationship with Erbakan's party at different timelines, testing the water in the USA before founding their parties and getting a positive feedback from there, being the product of 1980 military coup for Motherland Party and February 28 period which is military dominant period for Justice and Development Party, although the dominance of countryside for Motherland Party and province and suburb side for Justice and Development Party the parallelism of the political lines with the UN and IMF show that Erdogan and Ozal are quite similar leaders.

\section{Conclusion}

Conservatism, as a modern political ideology, came out at the end of the 18th century against the French revolution and enlightenment movement. The conservatism in Europe and North America did not spread except these continents. The most classic and basic principles were noted by Edmund Burke. There are many values on the basis of Conservative thinking. The conservatism, which includes values like tradition, family, religion, organic society, hierarchy, authority, was and has been used as a basic ideology in many developed countries. The conservative understanding in Turkey was handled in different ways at different government periods. Conservatism that came up in 1950s as nationalist conservatism, 1970s as Islamic and 1980s as Turkish conservatism has been effective on Turkish politics. In this study, 
Turkish conservatism is reviewed on Motherland Party which has an important place on right-wing of the Turkish politics. Motherland Party brought a fresh understanding its founder Turgut Ozal's conservatism in Turkey approach and especially with the economic policies it made unprecedented synthesis in Turkey.

Ozal, who had served long times in highest places both in public and private sector and gained experience in years he stayed in the USA, tried to utilize these experiences actively in politics. Although the notion of the conservatism was taken as fanaticism by the public, Ozal changed this understanding and mentioned that conservatism is a sophisticated understanding whenever he could. He often gave place to this in Motherland Party's programs. Even though Ozal implied that Motherland Party covered four major bases under the same roof, it is seen that Social Democratic notion stayed on the paper. Looking at the Motherland Party in Ozal period, the policies are quite parallel with the policies of the Thatcher governance in England and Reagon in America and in base that it has new right-wing understanding. The policies followed in Ozal period had major effects on Turkey and it pioneered the foundation of Istanbul Stock Exchange and flexible rate utilization. The New Right-wing policies that are followed supported by the public and Motherland Party hold the power without a coalition between 1983-1991 and policies that are followed in this period called as "Ozalism". After the Ozal period, ideological identity of Motherland Party changed a lot. At the Yılmaz period Motherland Party totally broke off with the conservative ideology and became a Liberal party. As a result, conservative ideology found place in Turkey as it had in many other countries and especially the Motherland Party in its governmental period utilized conservative ideology successfully in politics. The conservative ideology which had been in Turkey in a completely shallow way was understood more sophisticatedly by the public with the approach of the Ozal period.

\section{References}

Anavatan Partisi (ANAP) (1993). Parti Programı, Ankara.

Aydın, M. (2002). Bir Muhafazakârlık olarak din ve İslam. Tezkire, Yıl:11, Sayl: 27-28, Temmuz- Ekim, Ankara.

Aydın, H. (2008). Muhafazakâr düşünce temelinde demokrasi algısı ve Türkiye'de Adalet ve Kalkınma Partisi Örneği (Basılmamış Yüksek Lisans Tezi), Pamukkale Üniversitesi, Sosyal Bilimler Enstitüsü, Denizli.

Bora, T., \& Erdoğan. N. (2003). Muhafazakar Popülizm. In Ahmet Çigdem (Ed.), Modern Türkiye'de siyasi düşünce muhafazakarlık, Cilt: 5, İstanbul: Illetişim Yayınları.

Burke, E. (1986). Reflections on the Revolution in France, London: Penguin Books.

Civaoğlu, G. (2004). Özal ve Erdoğan, Milliyet Gazetesi, 20 Kasım.

Çaha, Ö. (2004). Muhafazakar düşüncede toplum. Uluslararası Muhafazakarlık ve Demokrasi Sempozyumu. (ss. 66-79), Ankara: Ak Parti Yayını.

Dursun, D. (2004). Muhafazakarlık ve Türk muhafazakarlığının sorun alanları. Uluslararası Muhafazakarlık ve Demokrasi Sempozyumu. (ss. 177-197), Ankara: Ak Parti Yayını.

Göle, N. (2002). Melez desenler İslam ve modernlik üzerine. 2. Baskı, Istanbul: Metis Yayınları.

Harries, O. (2004). Muhafazakârlığın anlamı. (Çev. M. Boşnak ), Liberal Düşünce 34, ss. 91-100.

Heywood, A. (2011). Siyasal ideolojiler, Bir Giriş, 3. Baskı, Ankara: Adres Yayınları.

Honderich, T. (1990). Conservatism. London: Hamish Hamilton.

İrem, C. N. (1997). Kemalist modernizm ve Türk gelenekçi-muhafazakârlı̆ı̆ıın kökenleri. Toplum ve Bilim. Sayı: 74, ss. 52-99.

Kirk, R. (2005). Süreklilik ve Değişim. (Çev. F. Çakır ). Muhafazakar düşünce. Cilt: 5, ss. 11- 26.

Kolat, G. (2002). Turkish Conservatism From A Comparative Perspective. Bilkent Üniversitesi Ekonomi ve Sosyal Bilimler Enstitüsü, (Unpublished Master's Dissertation), Ankara.

Mannheim, K. (2002). İdeoloji ve ütopya, çev. Mehmet Okyayuz, Ankara: Epos Yayınları.

Monk, L. H. (2004). Modern siyasal düşünceler. (Çev. S. Ü. Arat), İstanbul: Say Yayınları.

Morgil, O. (1996). Turgut Özal ve ekonomi politikaları. Devlet ve Siyaset Adamı: Turgut Özal içinde, Istanbul: Çetin Ofset Matbaası.

Öğün, S. S. (1997). Türk muhafazakarlığının kültür kökleri ve Peyami Safa'nın muhafazakar yanılgısı. Toplum ve Bilim, Sayı: 74.

Örs, B. (2012). 19. yüzyıldan 20. yüzyıla modern siyasal ideolojiler, İstanbul: İstanbul Bilgi Üniversitesi Yayınları.

Özipek, B. B. (2004). Muhafazakarlık akıl toplum siyaset. Ankara: Liberte Yayınları.

Oakeshott, M. (2001). Rationalism in politics and other essays. London: Methuen \& Co.

Rossiter, C. (1982). Conservatism in America. New York: Knopf.

Vural, M. (2003). Siyaset felsefesi açısından muhafazakârlık. Ankara: Elis Yayınları. 